\title{
HYPERMAGNESAEMIA AND ANAESTHETIC MANAGEMENT
}

\author{
Michael N. Skaredoff, Edward R. Roaf and Sanjay Datta
}

\begin{abstract}
The anaesthetic management of a pre-eclamptic parturient who was treated with high doses of magnesium sulphate and who developed hypermagnesaemia before delivery by Caesarean Section, is presented. The pharmacology of magnesium, particularly its effects at the neuromuscular junction, and clinical considerations of magnesium administration are discussed.
\end{abstract}

Key Words: Complications, pre-eclampsia, hypermagnesaemia; PHaRmacolOGY, magnesium.

WE REPORT a case of hypermagnesaemia in a pre-eclamptic patient presented for Caesarean Section. The pharmacology of magnesium is reviewed and the clinical implications of hypermagnesaemia in anaesthetic management are discussed.

\section{Case Report}

A 21-year-old primigravida at 27.5 weeks' gestation was transferred from a community hospital to the Boston Hospital for Women with the diagnosis of pre-eclampsia. She had been well until the day of admission, at which time she was noted to have a blood pressure of $170 / 120 \mathrm{~mm} \mathrm{Hg}$. After admission to the hospital, she was placed on bed rest and treated with phenobarbitone. On fundoscopic examination arteriolar spasm and fiat discs were observed. No exudates were seen. On abdominal examination, the fundus uteri measured $31 \mathrm{~cm}$. There was $4+$ pretibial oedema. Neurological examination revealed deep tendon reflexes $4+$ with clonus. Urinalysis revealed specific gravity of 1.015 , $4+$ bacteria and $4+$ albumin. Ultrasonic examination showed a foetus of 24 weeks' gestational size with hydrops.

Twelve hours after admission, magnesium

Michael N. Skaredoff, M.D., Fellow in Obstetric Anaesthesia; Edward R. Roaf, M.D., Instruction in Anaesthesia; Sanjay Datta, M.D., Assistant Professor of Anaesthesia; Harvard Medical School and Department of Anaesthesia, The Brigham and Women's Hospital, Boston, Massachusetts 02115, U.S.A.

Reprint requests to Michael N. Skaredoff, M.D., Assistant Professor of Anesthesiology, Health Sciences Center, State University of New York, Stony Brook, New York, 11795, U.S.A sulphate 4 grams was administered as an intravenous bolus. This was followed by further administration of magnesium sulphate by intravenous drip controlled by an infusion pump at a rate of one gram/hour. Ten hours later, when the serum magnesium level was $4.0 \mathrm{mmol} / 1$, the patient was brought to the operating room for Caesarean Section. Her blood pressure was $150 / 100 \mathrm{~mm} \mathrm{Hg}$. While oxygen was administered by face mask, an intravenous infusion of hydralazine $80 \mathrm{mg}$ in $150 \mathrm{ml}$ of five per cent dextrose in water was begun and continued until the blood pressure had fallen to $130 / 80 \mathrm{~mm} \mathrm{Hg}$. Anaesthesia was then induced with thiopentone $300 \mathrm{mg}$ intravenously and, facilitated by succinylcholine $100 \mathrm{mg}$ intravenously, the trachea was rapidly intubated. Anaesthesia was maintained with nitrous oxide and oxygen at flow rates of 3:31/min. After delivery of the neonate, morphine sulphate $5 \mathrm{mg}$ and diazepam $5 \mathrm{mg}$ were given intravenously, and the flow rates of nitrous oxide and oxygen were changed to $5: 21 / \mathrm{min}$. Anaesthesia lasted one hour and twenty minutes, after which the patient showed no efforts at ventilation. Testing with a peripheral nerve stimulator revealed a faint twitch, but no tetanic facilitation or twitch fade. The working diagnosis was a prolonged depolarizing succinylcholine blockade of neuromuscular transmission secondary to high magnesium levels, rather than a desensitization (Type II) block. While ventilation was maintained, it was elected to adopt an expectant attitude. Plasma cholinesterase was found to be 85 units $(\mathrm{N}=60-120 \mathrm{u})$. Urine output was $1 \mathrm{ml} \cdot \mathrm{kg}^{-1} / \mathrm{hr}$. Three hours later the patient resumed spontaneous respiration and the trachea was extubated without difficulty. Her 
post-operative course was uneventful and she was discharged a week later.

\section{Pharmacology of magnesium}

The body content of magnesium in the adult is $0.36 \mathrm{~g} \cdot \mathrm{kg}^{-1} .{ }^{1}$ Magnesium is found primarily in muscle and bone. Magnesium is absorbed from the gut by the same absorptive pathway as calcium. ${ }^{2}$ The normal plasma concentration ranges between 0.75 and $1.25 \mathrm{mmol} / 1 \mathrm{l}(1.5$ and $2.5 \mathrm{mEq} / \mathrm{l})$.

Like calcium, magnesium is intimately involved in the regulation of neuromuscular irritability and muscle contraction. For the anaesthetist the most important effect of magnesium involves the release of neurotransmitter at the neuromuscular junction. Under normal physiological conditions a nerve impulse activates adenylate cyclase which, in tum, produces cyclic AMP ${ }^{3,4}$ Cyclic AMP causes calcium channels ${ }^{5-7}$ to open. Calcium ion then enters, attaches itself to the vesicles that contain the neurotransmitter, ${ }^{8}$ and allows the vesicles to bind to releasing sites. ${ }^{9}$

Dodge and Rahamimoff ${ }^{9}$ in 1967 found that a minimum number of calcium ions was necessary for the acetylcholine vesicles to be released. In the presence of high concentrations of magnesium ions, fewer calcium ions bind to the vesicles. It was suggested that magnesium interferes with calcium binding in some manner. Colomo and Rahamimoff ${ }^{10}$ later found that magnesium was itself binding to the vesicle, preventing effective vesicle binding to the release sites. This ultimately resulted in decreased transmitter release. One then could have a curareform block with characteristic end plate potential depression. Del Castillo and Engbeak " found that the addition of curare to a nerve preparation in a magnesium bath intensified the reduction of end plate potentials, implying an increased blockade (Figures 1 \& 2). It was further observed that this prevention of acetylcholine release occurred particularly in the physiological $\mathrm{pH}$ range and that a small amount of calcium ion was sufficient to counteract the blockade.

To date the mechanism by which magnesium ion increases the duration of succinylcholine blockade has never been fully elucidated. Several hypotheses have been advanced. Ghoneim and Long ${ }^{12}$ suggest that since magnesium blockade at the neuro-muscular junction is partially the result of depression of the excitability of the muscle fiber membrane, the action of a depolarizing muscle relaxant might well be enhanced.

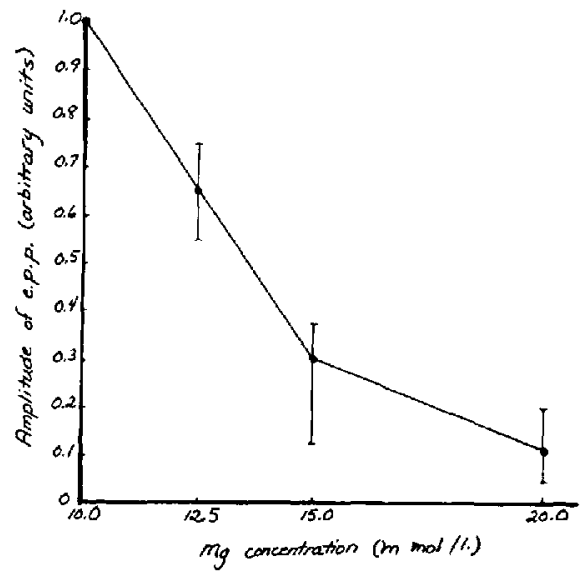

FIGURE 1 Effect of an increasing magnesium concentration on the amplitudc of the e.p.p. in "magnesium-blocked" preparations. Ordinate: amplitude of the e.p.p. in relative units; the height in preparations blocked by a solution containing $10 \mathrm{~m}$. mole/1. magnesium is taken as unit. Vertical lines drawn through the points (mean values) show the range of the observations. Abscissa: magnesium concentrations. Reproduced with permission from: del Castillo, J. and Engbaek, L. The nature of the neuromuscular block produced by magnesium. J. Physiol, 124: 370-384 (1954).

They also postulate that the potentiation of succinylcholine is not simply additive but the result of the two drugs acting on separate receptors. Freeman, ${ }^{13}$ on the other hand, suggests that succinylcholine, in concert with magnesium, may act by competing with calcium at the presynaptic membrane, leading to a decrease in acetylcholine release. As a third possibility, one might consider a magnesiumfacilitated emergence of a Phase II block. The precise cause of Phase II block is unknown, but depolarization of the end plate region by acetylcholine or succinylcholine is not maintained though the depolarizing drug is still present. ${ }^{14}$ Phase II block may be associated with a presynaptic site of action of acetylcholine and succinylcholine as suggested by Galindo..$^{15,16}$ Feldman and Tyrell ${ }^{17}$ have proposed that Phase II block represents a continuous and progressive binding of the depolarizing drug molecules to the intact receptor; this provides a significant degree of receptor occupancy and, therefore, adds a non-depolarizing component to the neuromuscular blockade. Taylor and Nedergaard ${ }^{18}$ suggest that the depolarizing agent accumulates inside the muscle cell and interferes with the action of acetylcholine. Katz and Thesleff ${ }^{14}$ 


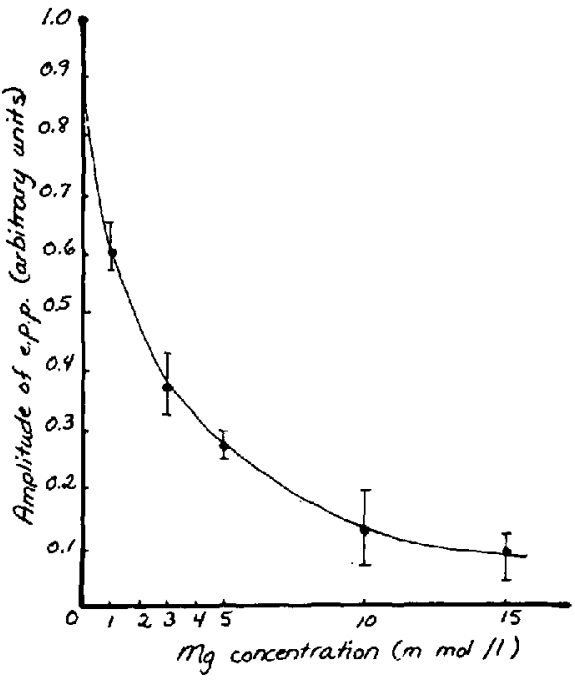

Figure 2 Effect of magnesium on the "curaree.p.p." Ordinate: amplitude of the e.p.p. in relative units. The height of the e.p.p. record in curarized preparations (soaked in $3 \times 10^{-6} \mathrm{~d}$-tubocurarine) is taken as unit. An increasing amount of $\mathrm{Mg}$ ions as indicated by the abscissa, was then added to the bathing fluid while keep constant the concentration of tubocurarine. Points represent mean values obtained in experiments. Vertical lines show the range. Reproduced with permission from: del Castillo, J. and Engbaek, L.: The nature of the neuromuscular block produced by magnesium. J. Physiol. 124: 370-384 (1954).

propose that there actually is a conformation change in the receptor and experimental evidence found by Ray and Ritter ${ }^{19}$ suggests that a Phase II block is, indeed, associated with conversion of the receptors to a desensitized, inactive form. Crul, et $a l^{20}$ suggest that with succinylcholine administration a subclinical Phase II block develops very rapidly, and that magnesium acts synergistically; the number of free, unchanged receptor sites susceptible to the action of succinylcholine decreases, with more sites becoming inactive, or "succinylcholinebound".

In addition, magnesium and calcium are necessary for the normal function of myosin ATP-ase in skeletal muscle contraction. ${ }^{21}$ Loeb $^{22}$ found in 1900 that raising the concentration of potassium or sodium increased neuromuscular excitability, whereas raising the concentration of calcium or magnesium depressed it. The interaction of calcium, magnesium and ATP-ase in muscles is quite complex and a precise mechanism has yet to be defined. ${ }^{23}$
Weber ${ }^{24}$ suggested that free calcium in a very low concentration might be needed for an optimal rate of hydrolysis of ATP. She also showed that actomysin ATP-ase was activated by 1 $2 \mu \mathrm{M}$ of free magnesium, but that at higher concentrations magnesium had an inhibitory effect unless sufficient free calcium was present. Yamamoto ${ }^{25}$ showed that in the presence of high concentrations of magnesium relative to ATP, the calcium dependence of the ATP-ase was independent of magnesium. It appeared, therefore, that calcium did not act by first binding with the ATP substrate but instead activated the ATP-ase by binding with the enzyme since, if the active substrate were calcium-ATP, its concentration would change when the magnesium concentration was changed. Thus, the substrate had to be magnesium-ATP.

Daniel $^{26}$ has postulated that when membrane pores are opened by removal of calcium from superficial membrane sites by depolarization or by drugs, both magnesium and calcium enter the myoplasm. Excess magnesium may compete with calcium for the activation site of the ATP-ase, thus opposing activation of contraction. In addition, the excitability of the muscle fiber membrane is lowered, resulting in reduced muscle contraction. ${ }^{27}$

Not only does magnesium affect striated muscle and the neuromuscular junction, but also cardiac and uterine syncytial muscle. Animal studies show a progressive depression of the inherent rhythmicity of the sinoatrial node as magnesium concentration is increased. ${ }^{28}$ Pacemaker cells have an unstable membrane potential that after each impulse declines to the firing level. This triggers the next impulse. ${ }^{29}$ The pacemaker potential reduction is due to a slow inward sodium current. ${ }^{30.31}$ The speed with which the membrane potential is reduced to the firing level determines the rate at which the cells discharge. Garnier ${ }^{32}$ and Chessais ${ }^{33}$ have shown that magnesium ion interferes with the sodium flux into the cells. Seifen ${ }^{34}$ and Hashimoto ${ }^{35}$ have demonstrated that magnesium also blocks the inward flow involved with diastolic depolarization. The end result is a lowered rate of discharge. The contractility of cardiac muscle is reduced as well ${ }^{36}$ on the basis of a direct stabilization of the cardiac transmembrane potential. ${ }^{37}$ By contrast, decreasing plasma magnesium concentration results in cardiac arrhythmias, such as frequent premature ventricular contractions, ventricular tachycardia and ventricular fibrillation. ${ }^{38-40}$ The uterus demonstrates 
a biphasic response to changes in magnesium ion concentration. Van Dyke and Hastings ${ }^{41}$ studied the response of the isolated guinea pig uterus to posterior pituitary extracts in different ionic environments. The absence of magnesium ions resulted in a decreased response, a $1 \mathrm{mM}$ concentration produced an optimal response, and a concentration of $3 \mathrm{mM}$ depressed the uterine muscle response. Genell ${ }^{42}$ and Fraser $^{43}$ demonstrated that the addition of magnesium ions to a magnesium-free bath increased the biphasic uterine response to whole posterior pituitary extract, to the oxytocic factor and to the vasopressor factor as well. When the magnesium concentration was $100-200 \mathrm{mg} / \mathrm{l}$, the response was optimal. A concentration of $500 \mathrm{mg} / \mathrm{l}$ reduced the uterine response. Spasmolytic action of magnesium was first demonstrated by Wodon. ${ }^{44,45} \mathrm{He}$ found that by adding successive doses of magnesium to an isolated guinea pig uterus, previously rendered tetanic by posterior pituitary extract, it became progressively relaxed. At a concentration of $4 \mathrm{~g} / \mathrm{l}$, rhythmic contractions reappeared. As the concentration of magnesium was further increased, uterine contractions gradually diminished, and at a concentration of $20 \mathrm{~g} / \mathrm{l}$ of magnesium, uterine contractions were entirely inhibited. At the same time, LaBarre and Wodon ${ }^{46}$ observed that in the decerebrated cat, magnesium relaxed the pitocininduced tetanic contractile state of its uterus.

In $1945 \mathrm{Abarbanel}^{47}$ showed in humans that a uterine tetanic contraction due to oxytocin could be abolished by magnesium. Hutchinson ${ }^{48}$ and his co-workers confirmed Abarbanel's work and felt that the action of the magnesium on the human uterus had two components: a direct cellular component and one that resulted from general muscle relaxation and vasodilation.

Until 1965 it was generally accepted that intravenous or intramuscular administration of high doses of magnesium to humans could cause anaesthesia. The main evidence for this was the report by Peck and Meltzer in 1916 of the successful use of magnesium to central nervous system tissue blocked central synaptic transmission with an effect that resembled general anaesthesia. However, Somjen and co-workers ${ }^{50}$ in 1966 reported that two subjects in whom magnesium ion concentration reached a level of 7.5 $\mathrm{mmol} / 1$ experienced neuromuscular paralysis, but had no decrease in consciousness or pain perception. Aldrete, et al. ${ }^{51}$ have stated that the apparent anaesthesia produced by magnesium may be explained on the basis of hypoxia and/or hypercarbia, but not necessarily by a central action on the brain.

\section{Clinical considerations}

Excessive magnesium concentrations are found in few disease states. Entities such as myxoedema, ${ }^{52}$ Addison's disease, ${ }^{53}$ and low output renal failure ${ }^{54,55}$ may all eventually result in an elevated magnesium ion levels. Characteristic symptoms include drowsiness and light coma when the serum level approaches 4.0 $\mathrm{mmol} / \mathrm{l}(8.0 \mathrm{mEq} / \mathrm{l})$. The electrocardiogram may demonstrate an increased $\mathrm{PR}$ interval and a broadening of the QRS complex. ${ }^{56}$

However, hypermagnesaemia is usually iatrogenic in origin, occurring when magnesium sulphate is used in the management of pregnancy-induced hypertension. The compound is effective in preventing convulsions in parturients with pre-eclampsia and in stopping them in eclamptic patients. The precise mechanism is not known and is the object of controversy. ${ }^{57}$ Although many feel ${ }^{51,58}$ that it is the neuromuscular blocking properties which are mainly responsible, recent evidence gathered by Borges and $\mathrm{Gucer}^{59}$ indicate that there may be a central depressant action. They showed in paralyzed animals that artificially-induced seizure activity became progressively suppressed as plasma concentrations of magnesium were increased.

In pre-eclampsia the therapeutic plasma concentration of magnesium is $2.0-3.5 \mathrm{mmol} / \mathrm{l}$ $(4.0-7.0 \mathrm{mEq} / 1) .^{56}$ As the level of magnesium exceeds $2.0 \mathrm{mmol} / \mathrm{l}$ deep tendon reflexes diminish and are absent at $5.0 \mathrm{mmol} / \mathrm{l}$. A moderate vasodilation is produced in pre-eclamptic patients with the intravenous administration of magnesium sulphate. Chesley and Tepper ${ }^{60}$ report that the decrease in blood pressure is temporary. Other effects of magnesium sulphate include an increase in uterine blood flow, ${ }^{61}$ in cerebral blood flow and in oxygen consumption. ${ }^{62}$ Ultimately, respiratory paralysis may occur when still higher concentrations are produced, but small doses of calcium can counteract this hazard. Cardiac changes such as complete heart block may be seen at levels less than $5.0 \mathrm{mmol} / \mathrm{l}$. Occasionally, an overdose of magnesium can cause a parathormone deficiency which will cause hypocalcaemia with central nervous system irritability and tetany. ${ }^{63}$

Magnesium therapy for pre-eclampsia may be instituted as follows. A loading dose of $20 \mathrm{ml}$ of 20 per cent magnesium sulphate ( 4 grams) is given intravenously, followed immediately by 
$20 \mathrm{ml}$ of 50 per cent magnesium sulphate $(10$ grams) intramuscularly and $10 \mathrm{ml}$ of 50 per cent magnesium sulphate ( 5 grams) every four hours intramuscularly ${ }^{64}$ thereafter, or $1.0-1.5 \mathrm{gram} /$ hour intravenously using an infusion pump. Subsequent doses are withheld, or the infusion is stopped, if the knee jerk is absent, the respiratory rate is reduced, and/or the urinary output is less than $100 \mathrm{ml}$ since the preceding dose. If respiratory depression supervenes, $10 \mathrm{ml}$ of 10 per cent calcium gluconate is given intravenously over one to three hours by infusion pump, in addition to standard methods of respiratory support.

Morris and Giesecke demonstrated in $1969^{66}$ that half the usual dose of succinylcholine sufficed to facilitate tracheal intubation during induction of general anaesthesia for Caesarean Section in pre-eclamptic patients treated with magnesium sulphate. The amount of d-tubocurarine needed for adequate relaxation was not altered by the increased serum magnesium level. Subsequent animal studies ${ }^{67}$ demonstrated that magnesium sulphate does, indeed, enhance the effect of d-tubocurarine. Ghoneim and Long, ${ }^{12}$ using phrenic nerve-diaphragm preparations, also showed that the amount of curare necessary for neuromuscular block was reduced in the presence of increased magnesium concentrations.

On the basis of the foregoing, it is advisable to limit the amount of succinylcholine in patients on magnesium therapy who receive general anaesthesia. Tracheal intubation, however, is accomplished with $1.0 \mathrm{mg}$ per $\mathrm{kg}$ body weight not only to overcome variation in patient sensitivity to succinylcholine but also to take advantage of the complete relaxation afforded by full dose in order to achieve smooth rapid intubation. Additional succinylcholine should be given sparingly and then only after neuromuscular transmission has recovered from effects of the initial dose. The use of a neuromuscular blockade monitor is therefore indicated.

\section{REFERENCES}

1. WeISBERG, H.F. Water, electrolytes, acid-base, and oxygen, Todd-Sanford's Clinical Diagnosis. 15th ed. Edited by I. Davidsohn and J.B. Henry. Philadelphia, Saunders (1974).

2. KEYNES, W.M. The parathyroid glands. The Physiological Basis of Medical Practice. Edited by C.H. Best and N.B. Taylor. Baltimore, Williams \& Wilkins (1966).

3. SutherLAND, E.W. \& RaLL, T. W. The relation of adenosine $3^{\prime}, 5^{\prime}$ phosphate and phosphorylase to the action of catecholamines and other hormones. Pharmacol. Rev. 12: 265 (1960).

4. HubBard, J.I. Mechanism of transmitter release. Prog. Biophys. Mol. Biol. 21: 33 (1970).

5. KATZ, B. \& MILEDI, R. The localization of calcium action at the nerve muscle junction, J. Physiol. 1964; I71: 10P (1964).

6. KaTZ, B. \& MILEDI, R. The effect of calcium on acetylcholine from motor nerve terminals. Proc. R. Soc. Lond. (Biol), 161: 496 (1965).

7. KATZ, B. \& Miledi, R. The timing of calcium action during neuromuscular transmission. J Physiol. 189: 535 (1967).

8. KANDEL, E.R. Small systems of neurons. Scientific American 241: 67 (1979)

9. Dodge, F.A. \& Rahamimoff, R. Co-operative action of calcium ions in transmitter release at the neuromuscular junction. J. Physiol. 193: 419 (1967).

10. Colomo, F. \& RahamimofF, R. Interaction between sodium and calcium ions in the process of transmitter release at the neuromuscular junction. J. Physiol. 198: 203 (1968).

11. del Castillo, J. \& Engbaek, L. The nature of the neuromuscular block produced by magnesium. J. Physiol. 124: 370 (1954).

12. Ghoneim, M. \& Long, J. The interaction between magnesium and other neuromuscular blocking agents. Anesthesiology 32: 23 (1970).

13. FreEMAN, S.E. Ionic influences on succinylcholine blockade of the mammalian neuromuscular junction. Brit. J. Pharmacol. 32: 546 (1968).

14. KaTz, B. \& TheslefF, S. A study of desensitization produced by acetylcholine at the motor endplate J. Physiol. 138: 63 (1957).

15. GALINDO, A. Depolarising neuromuscular block. J. Pharmacol. Exp. Ther. 178: 339 (1971).

16. Galindo, A. The role of prejunctional effects in myoneural transmission. Anesthesiology 36: 598 (1972).

17. Feldman, S.A. \& Tyrrell, M.F. A new theory on determination of action of the muscle relaxants. Proc. Roy. Soc. Med. 63: 692 (1970).

18. Taylor, D.B., \& Nedergaard, O.A. Relation between structure and action of quaternary amine neuromuscular blocking agents. Physiol. Rev. 45: 523 (1965).

19. RANG, H.P. \& RitTER, J.M. On the mechanism of densitization at cholinergic receptors. Mol. Pharmacol. 6: 357 (1970)

20. Crul, J.F., Long, G.T., Brunner, E.A., et al. The changing pattern of neuromuscular blockade caused by succinylcholine in man. Anesthesiology 27: 729 (1966).

21. HÄnZE, S. Der Magnesiumstoffwechsel. Stuttgart, Georg Thieme Verlag (1962).

22. LOEB, J. On the different effect of ions upon myogenic and neurogenic rhythmical contractions. and upon embryonic and muscular tissue. Am. J. Physiol. 3: 383 (1900).

23. Perry, S.V. General Discussion - Phosphorylation and the regulation of contraction of smooth muscle. In: Casteels, R., Godfraind, T., Ruegg, T.E. eds. Excitation contraction complex in smooth muscle, Elsevier, Amsterdan (1977).

24. WebEr, A. \& Herz, R. The binding of calcium 
to actomyosin systems in relation to their biological activity. J. Biol. Chem. 238: 599 (1963).

25. Yamamoto, $\mathrm{T}$. The $\mathrm{Ca}^{2+}-\mathrm{Mg}^{+}$dependent ATP-ase and the uptake of $\mathrm{Ca}^{2+}$ by the fragmented sarcoplasmic reticulum. In Tonomura, Y, Takeshita, T. eds. Muscle, protein, muscle contractions and cation transport. Baltimore: Univ. Park Press (1974)

26. DaniEL, E.E. Attempted synthesis of data regarding divalent ions in muscle junction. In: Paul, W.M., Daniel, E.E., Day, C.M., Monckton, G. eds. Muscle. Oxford: Pergamon Press (1964).

27. BRINK, F. The role of calcium in neural processes. Pharm. Rev, 6: 243 (1964).

28. SzeCKELY, P. The action of magnesium on the heart. Br. Heart J. 8: 115 (1946).

29. SCHER, A.M. Electrical Correlates of the Cardiac Cycle. In: Ruch, T. and Patton, H. eds. Physiology and Biophysics, Philadelphia: W.B. Saunders, (1960).

30. Rougier, O., Vassort, G., Garnier, D., et al. Existence and role of a slow inward current during the frog atrial action potential. Pflügers Arch Ges. Physiol. 308: 91 (1969).

31. Mascher, D., \& PEPER, K. Two components of inward current in myocardial muscle fibers. Pflügers Arch Ges. Physiol. 307: 190 (1969).

32. Garnier, D., Rougier, O., Gargoull, Y.M., et al. Analyse électrophysiologique du plateau des réponses myocardiques mis en evidence d'un courant entrant en absence d'ions bivalents. Pflügers Arch Ges. Physiol. 313: 321 (1969).

33. Chesnais, J.M., Coraboeuf, E., Sanvial, M.P., et al. Inhibition par les ions magnésium de la conductance sodique lente apparaissant sous l'effet des dépolarisation membranaires au niveau des fibres atriales de grenouille. ComptesRendues Acad. Sci. (D) (Paris) 273: 1594 (1971).

34. Siefen, E. Dependency on $\mathrm{Mg}$ - and Ca-concentration of cycle length in spontaneously beating guinea-pig atria. Pflügers Arch Ges. Physiol. 304: 46 (1968).

35. Hashimoto, K., Suzuki, Y. \& Chiba, S. Influence of calcium and magnesium ions on the sino-atrial node pacemaker activity of the canine heart. Tohoku J. Exp. Med. 113: 187 (1974).

36. Reiter, M. \& NoE, J. Die Bedeutung von Ca, $\mathrm{Mg}, \mathrm{K}$ und $\mathrm{Na}$ für die synthetische Erregungsbildung in Sinusknoten des Warmblüterherzens. Pflügers Arch Ges. Physiol. 269: 366 (1959).

37. Woods, W.T., Katholi, R.E., URTHULER, F., et al. Electrophysiological effects of magnesium on cells in the canine sinus node and false tendon. Circ. Res. 44: 182 (1979).

38. Chadda, H.D., Lichstein, E. \& Gupta, P. Hypomagnesemia and refactory cardiac arrhythmias in a non-digitalized patient. Amer. J. Cardiol. 31: 98 (1973).

39. KIM, Y.W., ANDREWS, C.L. \& RUTH, W.L Serum magnesium and cardiac arrhythmias with special reference to digitalis intoxication. Am. J. Med. Sci. 242: 87 (1961).

40. Loeb, H.S., Pietras, R.P., Gunnar, R.M., et al. Paroxysmal ventricular fibrillation in two patients with hypomagnesemia. Circulation 37 : 210 (1968).
41. van Dyke, H.B, \& Hastings, A.B. The response of smooth muscle in different ionic environments. Am. J. Physiol. 83: 563 (1928).

42. Genell, S. Die Bedeutung des Magnesjumions für die Motorik des überlebenden Uterus. Skandinav. Arch. f. Physiol. 80: 124 (1938).

43. Fraser, A.M. Effect of magnesium on response of uterus to posterior pituitary hormones. J. Pharm. Exp. Ther. 66: 85 (1939)

44. Wodon, J.L. Sur l'abolition de la téntanisation utérine par les sels magnésiques. Compt. Rend. Soc. de Biol. 103: 529 (1929).

45. WODON, J.L. De l'abolition des sels magnésiques de la contraction utérine obtenue par divers agents tétanisants. Compt. Rend. Soc. de Biol. 103: 930 (1929).

46. LaBarRe, J., \& WODON, J.L. Démonstration in vivo de l'action decontracturant du sulfate magnésique sur uterus tétanisé par l'extrait posthypophysaire. Compt. Rend. Soc. de Biol. 103: 531 (1929)

47. ABARBANEL, A.R. The spasmolysant action of magnesium ions on the tetanically contracting human gravid uterus. Am. J. Obstet. Gynecol. 49: 473 (1945).

48. Hutchison, H.T., Nichols, M.M., KuHN, C.R., et al. Effects of magnesium sulfate on uterine contractility, intrauterine fetus and infant. Am. J. Obstet. Gynecol. 88: 747 (1964)

49. PeCK, C.H. \& Melrzer, S.J. Anesthesia in human beings by intravenous injection of magnesium sulphate J.A.M.A. 68: 1131 (1916).

50. Somjen, G., Milmy, M. \& Stephen, C.R Failure to anesthetize human subjects by intravenous administration of magnesium sulfate. $\mathrm{J}$. Pharm. Exp. Ther. 154: 652 (1966).

51. Aldrete, J.A., BaRnes, D.R. \& Aikawa, J.K. Does magnesjum produce anesthesia? Evaluation of its effects on the cardiovascular and neurologic systems. Anes. Analg. (Cleve.) 47: 428 (1968).

52. JoNes, J.E., DesPer, P.C., SHANe, S.R., et al Magnesium metabolism in hyperthyroidism and hypothyroidism. J. Clin. Invest. 45: 891 (1966).

53. WACKER, W.E.C. Magnesium, in: Mineral Metabolism: An advanced treatise: Vol. 2, The elements, Parts A-B, Part A. Edited by C.L. Comar and F. Bronner. New York, Academic Press (1964).

54. Robinson, R.R., Murdugh, H.V. \& Peschel, E. Renal factors responsible for hypermagnesium of renal discase. J. Lab. \& Clin. Med. 53: 572 (1959).

55. Randall, R.E., Cohen, M.D., Spray, C.C. et al. Hypermagnesemia in renal failure: Etiology and toxic manifestations. Ann. Int. Med. 61: 73 (1964).

56. WACKER, W.E.C. \& PARISI, A. Magnesium metabolism. N. Eng. J. Med. 278: 658, 712, 772 (1968).

57. SHELLY, W.C. \& Gutsche, B.B. Magnesium and seizure control. Am. J. Obstet. Gynec. 136: 146 (1980).

58. Hibiard, B.J. \& Rosen, M. The management of severe pre-eclampsia and eclampsia. Br. J. Anaesth. 49. 3 (1977).

59. Borges, L.F. \& GuCER, G. Effect of magnesium on epileptic foci. Epilepsia 19: 81 (1978) 
60. Chesley, L.C. \& Tepper, I. Plasma levels of magnesium attained in magnesium sulfate therapy for pre-eclampsia and eclampsia. Surg. Clin. N. Amer, 353 April (1957).

61. Harbert, G.M., Cornell, G.W. \& ThornTON, W.N. Effect of toxemia therapy on hemodynamics. Am. J. Obstet. Gynec. 105: 94 (1969)

62. MCCALI, M.L. \& Sass, D. The action of magnesium sulfate on cerebral circulation and metabolism in toxemia of pregnancy. Am. J. Obstet. Gynec. 7l: 1089 (1956).

63. Eisenbut, E. \& LoBue, C. Hypocalcemia after therapeutic use of magnesium sulfate. Arch. Int. Med. 136: 688 (1976).
64. Pritchard, J. \& Pritchard, S. Standardized treatment of 154 consecutive cases of eclampsia. Am. J. Obstet. Gynec. 123: 543 (1975).

65. Chesley, L.C. Hypertensive Disorders in Pregnancy. New York, Appelton-Century-Crofts (1975).

66. Morris, R. \& Giesecke, A. Potentiation of muscle relaxants by magnesium sulfate therapy in toxemia of pregnancy. So. Med. J. 61: 25 (1968)

67. Giesecke, A.H., Morris, R.E., Dalton, M.D., et al. Of magnesium muscle relaxants, toxemic parturients and cats. Anes. Analg. (Cleve.) 47: 689 (1968)

\section{RÉSUMÉ}

Les auteurs rapportent un cas d'apnée prolongée après administration de succinylcholine, chez une parturiente en pré-éclampsie et accouchée par césarienne; la patiente avait été traitée au sulfate de magnésie à doses élevées avant son intervention et présentait une hypermagnésémie. La pharmacologie du magnésium et, en particulier ses effets au niveau de la fonction neuro-musculaire ainsi que les applications cliniques de l'administration de cet agent sont discutés. 